\title{
KELEMBAGAAN PENGUPAHAN PADA INDUSTRI TEKSTIL DI JAWA BARAT
}

\author{
Erna Maulina ${ }^{1}$, dan Nur Efendi ${ }^{2}$ \\ ${ }^{1}$ Fakultas Ilmu Sosial dan Ilmu Politik Universitas Padjadjaran \\ ${ }^{2}$ Jurusan Administrasi Bisnis FISIP Universitas Lampung \\ E-mail.erna_500@yahoo.com; nurefendi10@gmail.com
}

\begin{abstract}
ABSTRAK. Industri tekstil adalah salah satu industri padat karya yang terkena dampak langsung dari kebijakan pengupahan yang ditetapkan oleh pemerintah. Tujuan dari tulisan ini adalah untuk memberikan sebuah analisis kritis atas kelembagaan pengupahan pada industri tekstil di Jawa Barat. Dalam penelitian ini digunakan metode kualitatif dengan pendekatan studi kasus. Sumber data penelitian diperoleh melalui teknik wawancara, observasi dan dokumentasi. Hasil penelitian menunjukkan bahwa kelembagaan pengupahan pada industri tekstil di Jawa Barat di tandai oleh banyaknya pelanggaran atas aturan pengupahan dan lemahnya upaya penegakan oleh pemerintah. Pelanggaran yang terjadi diantaranya adalah membayar pekerja di bawah ketentuan upah minimum atau tidak sesuai dengan norma pengupahan. Penegakan aturan yang diterapkan oleh pemerintah tanpa diikuti sanksi hukum telah memunculkan aturan informal dalam bentuk konvensi untuk memberikan suap kepada oknum pengawas. Penelitian ini menyimpulkan bahwa kelembagaan pengupahan pada industri tekstil di Jawa Barat ditandai oleh masih banyak perusahaan yang melanggar aturan pengupahan. Hambatan dalam kelembagaan pengupahan ini adalah mekanisme penetapan upah minimum yang kurang memperhatikan kondisi riil perusahaan tekstil dan lemahnya penegakan aturan formal oleh pemerintah.
\end{abstract}

Kata kunci: Kelembagaan, aturan formal, upah minimum, penegakan aturan

\section{INSTITUTIONAL REMUNERATION ON TEXTILE INDUSTRY IN WEST JAVA}

ABSTRACT. The textile industry is one of the labor-intensive industries that are directly affected by wage policy set by the government. The purpose of this paper is to provide a critical analysis of the institutional remuneration in the textile industry in West Java. This study used qualitative methods and a case study approach. Sources of research data obtained through interview, observation and documentation. The results showed that the institutional remuneration in the textile industry in West Java marked by a number of violations of the rules of remuneration and weak enforcement of rules by the government. Violations include paying workers below the minimum wage or not in accordance with the wage norm. Enforcement of the rules applied by the government without legal sanction followed have led to informal rules in the form of a convention to give a bribe to the officers supervisor. This study concludes that the institutional remuneration in West Java's textile industry is characterized by many companies that violate the rules of remuneration . Institutional remuneration barriers are minimum wage fixing mechanism is less attention to the real condition of the textile companies and weak enforcement of rules by the government .

Key words: Institutional, formal rules, minimum wage, enforcement of rules

\section{PENDAHULUAN}

Industri tekstil adalah satu industri yang terkena dampak langsung dari arus globalisasi yang melanda Indonesia. Industri tekstil mengalami decline sejak diberlakukannya kesepakatan ATC (Agreement on Textiles and Clothing) oleh WTO tentang peng0urangan kuota pada akhir Desember 1994 dan krisis tahun 1997-1998. Penurunan ini tidak hanya terjadi dalam hal penjualan produk tekstil tetapi juga dalam jumlah perusahaan yang beroperasi. Pengurangan pajak dan tarif masuk menyebabkan pasar domestic dibanjiri oleh produk tekstil impor. Kondisi ini semakin diperparah dengan disepakatinya perjanjian ACFTA pada tahun 2010 yang melegalkan produk tekstil asal China masuk ke Indonesia tanpa pembatasan. Turunnya daya saing industri tekstil ini tidak hanya berdampak pada lemahnya penguasaan pasar tetapi juga pada jumlah perusahaan yang beroperasi.

Jawa Barat sebagai salah satu daerah produsen tekstil dan produk tekstil (TPT) terbesar di Indonesia (lebih kurang 57\%) juga mengalami dampak dari persaingan global ini. Sari dalam sebuah artikelnya mengatakan bahwa "data dari Asosiasi Pertekstilan Indonesia (API) mengungkapkan, tercatat 467 industri TPT gulung tikar dalam kurun waktu
2002 - 2007. Sebagian besar di antaranya adalah industri TPT dengan kategori industri menengah besar yang memiliki tenaga kerja antara 3.000-4.000 orang. Sebagian besar industri yang tutup itu berlokasi di Jawa Barat (227 pabrik)". Untuk saat ini, data tentang jumlah perusahaan tekstil yang beroperasi di Jawa Barat masih simpang siur. Data Kementerian Perindustrian menunjukkan bahwa sampai dengan September 2012 jumlah unit usaha tekstil di Jawa Barat adalah sebanyak 754 unit usaha. Jumlah ini sangat berbeda dengan data dari Dinas PerindustrianJawaBaratyangmenunjukkanbahwajumlah unit usaha tekstil di Jawa Barat adalah 713 unit usaha. Indonesian Textile \& Garment Guiding Book 2012-2014 yang diterbitkan oleh API Jawa Barat mencatat terdapat 670 perusahaan TPT yang beroperasi di Jawa Barat Semakin beratnya beban yang harus dipikul oleh industri tekstil bukan hanya disebabkan oleh persaingan dalam industri tetapi juga oleh aturan pengupahan yang progresif. Hal ini disebabkan karena industri tekstil adalah industri yang padat karya. Tujuan dari tulisan ini adalah untuk memberikan sebuah analisis kritis atas kelembagaan pengupahan pada industri tekstil di Jawa Barat.

Institutional Economics Theory merupakan solusi yang diberikan atas kegagalan teori ekonomi neoklasik dalam menjelaskan fenomena ekonomi dalam dunia 
nyata. Mainstream yang digunakan oleh aliran ekonomi klasik dan neoklasik bahwa manusia adalah makhluk yang rasional sehingga utilitas segala sesuatunya dinilai dengan menggunakan pemikiran yang rasional ternyata tidak benar. Keterbatasan rasional yang dimiliki oleh manusia tidak memungkinkannya mengetahui segala sesuatu terutama yang akan terjadi dimasa depan. Ekonomi kelembagaan berupaya untuk mempelajari fenomena ekonomi yang muncul di dunia nyata, dengan pemahaman bahwa fenomena ekonomi tidak selamanya bisa dijelaskan dengan rasionalitas manusia.

North mendefinisikan kelembagaan sebagai "the humanly devised constraints that structure political, economic and social interaction. They consist of both informal constraints (sanctions, taboos, customs, traditions, and codes of conduct), and formal rules (constitutions, laws, property rights).

North juga mengatakan bahwa: "An institution can be defined as a set of formal and informal rules, including their enforcement arrangements. The general aim of institutions is to provide individuals with a set of rules that guide or determine their individual behaviour. Thus, institutions help to reduce uncertainty"

Menurut Eriksson Skoog, kelembagaan dalam arti aturan-aturan dan norma-norma berperilaku secara formal dan informal,menyediakan kerangkakerjauntuk interaksi sosial dengan mendefinisikannya sebagai aturan main. Aturan ini secara krusial berdampak pada cara individu dan organisasi berperilaku dan berinteraksi. Pada level makro, Verriest, dkk menginterpretasikan kelembagaan sebagai formal constraints dalam struktur interaksi manusia seperti aturan-aturan, hukum dan konstitusi. Interaksi ini membawa konsekuensi pada struktur insentif dalam pertukaran yang dilakukan manusia. Kelembagaan bukan hanya seperangkat aturan formal dan informal tetapi harus diikuti dengan penegakannya.

Dengan demikian ada tiga komponen utama kelembagaan, yaitu seperangkat aturan formal, seperangkat aturan informal (norma) dan kepatuhan dan mekanisme pelaksanaan, yang menurut North menentukan kinerja ekonomi. Kelembagaan dalam suatu masyarakat diikuti dan di laksanakan sebagai suatu keharusan. Kelembagaan merupakan panduan bagi setiap individu dalam berinteraksi ketika mereka ingin memenangkan permainan melalui kombinasi keahlian,strategi, dan koordinasi, baik secara adil maupun tidak adil. Adanya informal institutions sebagai constraint, menjadikan kelembagaan sebagai collective action in control of individual action. Adanya peluang dan hambatan mengharuskan individu untuk berinteraksi satu sama lain agar memperoleh hasil yang optimal. Hambatan bagi sese-orang menjadi peluang bagi yang lainnya.

Sementara itu Klijn \& Koppenjan menyatakan bahwa kelembagaan adalah sistem aturan. Dan bahkan banyak penulis menganggap aturan sebagai karakteristik kelembagaan. Kelembagaan memberikan aturan, kendala dan insentif yang merupakan instrumen untuk tata kelola pertukaran. Mekanisme tata kelola ini dapat dilakukan secara formal atau informal.
Meskipun interaksi antar individu dan kelompok telah dipandu dengan aturan formal dan informal, tidak berarti bahwa interaksi diantara mereka menjadi lebih murah dan efisien. Aturan main tidak selalu dan bahkan diciptakan tidakuntuk efisien. Aturan diciptakan untuk menurunkan ketidakpastian yang disebabkan oleh incomplete information dan bounded rationality dalan pertukaran, dan oleh sebab itu ada cost of transaction yang harus ditanggung oleh mereka yang melakukan interaksi pertukaran.

Secara khusus, istilah institutions dapat berarti norma, yaitu aturan yang mengarahkan perilaku melalui sanksi, tapi istilah ini juga dapat berarti sebuah organisasi atau badan institusi. Kelembagaan tidak sama dengan organisasi. Kelembagaan adalah rules of the game, sedangkan organisasi adalah the players. Dan yang lebih penting lagi adalah the way the game is played.

Dengan demikian, ada 3 (tiga) aspek yang saling berkaitan dalam membahas kelembagaan yaitu adanya aturan main, aktor, dan cara permainan itu dimainkan.

\section{METODE}

Penelitian ini termasuk ke dalam tipe penelitian deskriptif eksploratif. Untuk mendeskripsikan dan menjelaskan kelembagaan pengupahan pada industri tekstil maka digunnakan metode kualitatif dengan pendekatan studi kasus. Objek penelitian ini adalah kelembagaan pengupahan pada industri tekstil di Jawa Barat. Dalam penelitian ini, kelembagaan pengupahan didefinisikan sebagai pelaksanaan aturan pengupahan formal dan informal pada industri tekstil Jawa Barat.

Untuk keperluan pengumpulan data maka lokasi penelitian dipilih dari kabupaten/kota yang memiliki jumlah perusahaan tekstil yang paling banyak dan yang relatif sedikit, yaitu Kabupaten Bandung dan Sumedang. Informal penelitian ini terdiri dari pemiliki atau yang mewakili perusahaan tekstil yang berlokasi di Kabupaten Bandung dan Sumendang, Kepala Dinas Tenaga Kerja di Kabupaten Bandung dan Sumedang, dan beberapa orang tenaga kerja. Sumber data utama dalam penelitian ini diperoleh melalui teknik wawancara, observasi, dan dokumen-dokumen, atas pelaksanaan aturan pengupahan pada Industri Tekstil.

Pengujian validitas data dilakukan dengan cara triangulasi. Sedangkan pengujian reliabilitas dilakukan dengan (1) Memeriksa transkrip untuk memastikan bahwa tidak adanya kesalahan yang dilakukan sepanjang proses penyusunan transkrip tersebut, dan (2) Memastikan bahwa tidak ada kesalahan dalam memberikan kode dan mengartikan kode. Karena pengkodean dilakukan selama proses penelitian maka peneliti harus selalu memeriksa dan memastikan tidak ada kode yang sama dengan definisi yang berbeda. Data yang diperoleh melalui penelitian ini dianalisis melalui tiga tahapan, yaitu reduksi data, tampilan data, dan penarikan kesimpulan.

\section{HASIL DAN PEMBAHASAN}

Kelembagaan pengupahan pada industri tekstil di Jawa Barat terdiri atas seperangkat aturan main yang 
formal dan dan kendala-kendala informal yang sengaja diciptakan dalam interaksi antar aktor. Dalam konteks ini aturan formal yang dimaksud adalah Undang-Undang Nomor 13 Tahun 2003 Tentang Ketenagakerjaan. Pada pasal 88 (4) dalam undang-undang ini dikatakan bahwa "Pemerintah menetapkan upah minimum berdasarkan kebutuhan hidup layak dan dengan memperhatikan produktivitas dan pertumbuhan ekonomi”. Selanjutnya dalam pasal 1 (1) Peraturan Menteri Tenaga Kerja dan Transmigrasi Nomor 7 Tahun 2013 Tentang Upah Minimum dikatakan bahwa "Upah Minimum adalah upah bulanan terendah yang terdiri atas upah pokok termasuk tunjangan tetap yang ditetapkan oleh gubernur sebagai jaring pengaman". Dan pada pasal 3 (1) Peraturan Menteri ini juga dikatakan bahwa "penetapan Upah Minimum didasarkan pada Kebutuhan Hidup Layak (KHL) dengan memperhatikan produktivitas dan pertumbuhan ekonomi.

Penghitungan besarnya KHL mengacu pada Peraturan Menteri Tenaga Kerja dan Transmigrasi Nomor 13 tahun 2012, bahwa Dewan Pengupahan menetapkan KHL dengan menghitung 60 komponen yang harus dipenuhi dalam penetapan upah buruh. Ke-60 komponen tersebut terdiri dari makanan dan minuman (11 items), sandang (13 items), perumahan (26 items), pendidikan (2 item), kesehatan (5 items), transportasi (1 item), serta rekreasi dan tabungan (2 item).

Aktor-aktor yang bermain dalam kelembagaan pengupahan pada industri tekstil adalah adalah pengusaha, buruh, asosiasi pengusaha, dan pemerintah yang juga merangkap sebagai regulator. Selanjutnya, bagaimana aturan pengupahan dimainkan menjadi sangat menarik karena dalam konteks industri tekstil penerapan aturan tentang upah minimum ini belum bisa berjalan secara optimal. Berbagai kendala muncul bukan hanya karena keengganan pengusaha untuk melaksanakannya tetapi juga kelayakan upahnya masih terus dipertanyakan. Apalagi dengan adanya kecenderungan bahwa upah minimum setiap tahunnya harus dinaikkan di bawah ancaman aksi buruh. Hal-hal semacam ini membuat pengusaha tekstil yang notabene dipaksakan untuk padat karya, mempertanyakan keberpihakan pemerintah pada dunia usaha. Ada anggapan dari pengusaha bahwa bahwa aturan pengupahan cenderung mengikuti keinginan buruh.

Ada dua kondisi yang terjadi dalam pelaksanaan aturan tentang upah minimum ini, pertama, perusahaan yang secara komulatif membayar tenaga kerjanya di bawah upah minimum. Kedua, perusahaan yang secara komulatif upah tenaga kerjanya di atas upah minimum namun belum sesuai ketentuan upah minimum. Kondisi yang pertama lebih banyak dijumpai pada perusahaanperusahaan tekstil berskala kecil dan menengah (IKM). Sebagai contoh, sekitar 50\% perusahaan tekstil berskala IKM di Kabupaten Bandung melakukan pelanggaran terhadap aturan pengupahan. Dalam hal ini, ukuran dan ketidakmampuan perusahaan menjadi alasan utama untuk tidak membayar upah sesuai dengan ketentuan pengupahan. Kecenderungan untuk tidak membayar upah minimum ini juga disebabkan beberapa alasan, pertama, karena kurangnya pengetahuan tenaga kerja tentang hak-haknya. Hal ini secara jelas memperlihatkan bahwa ada keengganan pihak perusahaan untuk membayar upah sesuai dengan upah minimum. Kedua, berkaitan dengan kualitas tenaga kerja yang masih rendah. Sebagian pengusaha kecil dan menengah menolak jika aturan pengupahan ini disamakan dengan perusahaan besar. "Perusahaan besar memiliki segalanya, memiliki modal yang kuat, teknologi yang bagus dan tenaga kerja yang juga bagus. Dan dengan kondisi dan kualitas tenaga kerja yang lebih baik, perusahaan besar ternyata hanya menggunakan upah yang minimal. Sedangkan perusahaan yang kecil, minimalnya saja tidak mampu." Oleh karena itu, keengganan untuk membayar upah minimal sebenarnya bukan tanpa alasan. Seharusnya pemerintah bisa membuat batasan yang jelas tentang subjek dari upah minimum ini karena kompetensi tenaga kerja yang dimiliki perusahaan besar berbeda dengan perusahaan kecil dan menengah. Pelaksanaan aturan tanpa memperhatikan kompetensi dan ukuran perusahaan akan berdampak buruk terutama bagi perusahaan kecil dan menengah.

Hasil penelitian ini juga menunjukkan bahwa kualitas tenaga kerja yang dimiliki perusahaan tekstil kecil dan menengah memang tidak sebaik tenaga kerja yang di perusahaan besar. Hal ini terjadi karena ada kecenderungan dari calon tenaga kerja untuk mengutamakan bekerja di perusahaan besar dan menjadikan perusahaan kecil dan menengah hanya sebagai batu loncatan untuk bisa masuk kesana. Calon tenaga kerja yang gagal masuk ke perusahaan besar dan tidak memiliki keterampilan ini akhirnya mendatangi perusahaan haji-haji (istilah untuk pengusaha tekstil pribumi) untuk melamar pekerjaan.

Kondisi tenaga kerja yang seperti ini ternyata dialami oleh hampir semua perusahaan tekstil di Jawa Barat. Rendahnya kualitas ini bukan hanya disebabkan karena calon yang masuk tidak memenuhi kualifikasi standar tetapi juga sistem rekrutmen tenaga kerja yang lebih mengutamakan faktor emosional daripada rasional. Pada kebanyakan perusahaan tekstil kecil dan menengah, pekerja dapat masuk dan keluar tanpa proses yang rumit, dan mereka mulai bekerja di pabrik dari tukang sapu sampai menjadi operator mesin.

Banyaknya perusahaan tekstil yang membayar upah di bawah upah minimum disebabkan oleh 3 (tiga) alasan. Pertama, rendahnya kemampuan finansial perusahaan, kedua, adanya upaya secara sadar untuk menghindari kewajiban membayar upah minimum. Dan ketiga, upaya untuk menghindari kewajiban ini disebabkan oleh karena rendahnya kualitas tenaga kerja yang masuk ke industri tekstil yang berskala kecil dan menengah, sehingga tidak adil jika upahnya juga disamakan dengan upah tenaga kerja di perusahaan besar yang juga menggunakan standar upah minimum.

Untuk alasan yang pertama memang tidak ada upaya yang dapat dilakukan oleh pekerja dan pemerintah untuk memperbaiki kondisi ini. Banyaknya perusahaan tekstil yang ditutup pasca krisis ekonomi tahun 1998 
dan hantaman tekstil impor dari China menyebabkan sebagian besar perusahaan bertahan dengan melakukan efisiensi biaya tenaga kerja. Efisiensi ini dilakukan dengan cara membayar upah di bawah upah minimum dan tidak melakukan pemutusan hubungan kerja (PHK). Kebijakan perusahaan yang pro job ini ternyata bisa menyelamatkan ribuan tenaga kerja dari ancaman PHK meskipun mereka harus menerima upah yang rendah.

Untuk alasan yang kedua, dimana pengusaha berupaya untuk menunda atau bahkan tidak membayar upahsesuaidenganupahminimumpadahal secarafinansial mampu. Inilah yang disebut sebagai hukum ekonomi. Ini diindikasikan dengan adanya sejumlah pengusaha yang membayar upah tidak sesuai dengan norma pengupahan dan pengusaha yang hanya menjalankan sebagian aturan pengupahan. Hasil pemeriksaan yang dilakukan oleh Bidang Pengawasan Disnakertrans Kabupaten Bandung menunjukkan bahwa penerapan upah minimum baru berjalan fifty fifty, ini berarti bahwa perusahaan tekstil yang ada di Kabupaten Bandung baru melaksanakan $50 \%$ kewajiban pengupahannya. Dan ini ternyata diakui oleh pengusaha tekstil bahwa mereka memang baru menjalankan sebagian dari aturan pengupahan yang diatur dalam Peraturan Menteri Tenaga Kerja dan Transmigrasi Nomor 7 Tahun 2013. Pada sisi lain, juga banyak perusahaan yang secara komulatif upah tenaga kerjanya sudah mencapai upah minimum namun secara normatif masih melanggar ketentuan tentang upah minimum. Atau, meskipun mereka sudah memberikan upah sesuai dengan aturan namun ternyata tidak berlaku untuk semua tenaga kerja.

Untuk alasan ketiga, bahwa banyak pengusaha yang membayar upah di bawah upah minimum disebabkan karena rendahnya kualitas tenaga kerja yang menjadi input dalam proses produksi. Kondisi ini disebabkan karena perusahaan tekstil yang berskala kecil dan menengah hanya kebagian residu calon tenaga kerja, serta praktek rekrutmen dan seleksi yang longgar. Rendahnya kemampuan perusahaan untuk membayar upah menjadi penyebab utama dari kurangnya minat calon tenaga kerja untuk masuk ke perusahaan kecil dan menengah dan terjadinya migrasi tenaga kerja dari perusahaan kecil dan menengah ke perusahaan besar. Jelas sekali bahwa motif ekonomi menjadi alasan bagi tenaga kerja untuk berpindah dari satu perusahan ke perusahaan lainnya. Bahkan seperti dikatakan oleh seorang pengusaha, "pekerja yang unskill pun yang mereka rancang itu bukan meningkatkan kualitas kerja tapi bagaimana gaji bisa lebih besar.'

Stigler menjelaskan bahwa tujuan dilembagakannya regulasi adalah untuk melindungi kepentingan public. Dalam hal penetapan upah minimum, secara umum tujuannya adalah untuk melindungi kaum buruh yang jumlahnyamencapai 110juta padabulanAgustus 2013 dan 21 juta di antaranya bekerja di sektor industri pengolahan. Pemerintah sendiri menyadari bahwa tidak semua buruh yang bekerja di sektor pengolahan ini adalah tenaga kerja yang terampil dan terdidik. Agar buruh yang banyak ini bisa mencukupikebutuhanhidupnyamakaditetapkanlahaturan tentang upah minimum yang merupakan upah terendah yang diterima oleh seorang tenaga kerja per bulannya. Dan seperti juga dikatakan oleh De Cenzo \& Robbins, pemerintah menetapkan upah minimum dalam rangka melindungi kelompok tertentu, yaitu kaum buruh. Bagi perusahaan, adanya aturan upah minimum ini menjadi suatu pilihan optimal yang bisa diambil meskipun itu tidak memuaskan bagi mereka. Karena seperti dikatakan oleh North, kerangka kelembagaan menentukan jenis keterampilan dan pengetahuan yang diinginkan untuk bisa dibayar secara maksimum. Dengan demkian, kontrak pengupahan yang seharusnya dilakukan oleh perusahaan dengan pekerja, berganti menjadi komitmen perusahaan untuk membayar upah minimum. Tinggal sekarang bagaimana aturan itu dilaksanakan baik oleh perusahaan maupun oleh pemerintah.

Fakta bahwa banyak perusahaan yang masih membayar buruh di bawah upah minimum juga diakui oleh seorang pengawas di sebuah pabrik tenun di Majalaya. Menurut beliau, upah yang diterima dengan bekerja di perusahaan pribumi jauh lebih kecil dibanding dengan perusahaan milik non pribumi. Dengan demikian, bukan masalah besar atau kecilnya ukuran perusahaan tetapi siapa yang mengelola. Jika apa yang dikatakan pekerja pengawas ini benar bahwa jika dikelola orang non pribumi upahnya bisa mencapai upah minimum, berarti ada perbedaan perilaku buruh pada saat bekerja dengan orang pribumi dan non pribumi. Artinya, jika bekerja di perusahaan non pribumi, buruh bisa sedikit lebih keras menekan pengusaha untuk membayar upah sesuai dengan ketentuan pemerintah. Hal ini berbeda dengan sikap buruh yang bekerja untuk "Pak Haji" dimana mereka bisa lebih melunakkan tuntutannya.

Hampir sama dengan pekerja pengawas tadi, seorang buruh yang bekerja pada sebuah pabrik tekstil yang baru satu tahun beroperasi di Majalaya. Mengatakan bahwa upah yang dia terima masih jauh di bawah upah minimum. Sampai saat ini beliau masih dibayar Rp 850.000,00 sebulan ditambah dengan uang makan Rp 5.000,00 sehari. Dibandingkan dengan upah minimum Kabupaten Bandung pada tahun 2013 yang mencapai Rp 1.388.333,00, tentunya upah yang diterima buruh ini masih jauh dari dari KHL. Dengan demikian apakah memang ada kecenderungan bahwa upah yang dibayar oleh pengusaha pribumi lebih rendah dari upah minimum dan sikap buruh lebih lunak jika yang memiliki perusahaan adalah orang pribumi? Hipotesis ini tentunya harus diuji melalui penelitian yang lain. Namun dari beberapa keterangan yang diberikan kedua pekerja pabrik ini, serta pengakuan pengusaha yang kebetulan adalah pribumi, memang benar bahwa mereka belum membayar upah sesuai dengan upah minimum. Penjelasan yang cukup logis untuk hal ini adalah bahwa rendahnya upah yang dibayar pengusaha berkaitan dengan kualitas tenaga kerja. Namun demikian buruh diuntungkan dengan sistem rekrutmen dan seleksi yang tidak menuntut banyak persyaratan formal serta hubungan kerja yang bernuasa kekeluargaan. Hal inilah yang membuat buruh bisa menerima kondisi pengupahan yang masih belum mencapai KHL dan upah minimum seperti yang di atur oleh pemerintah. 
Masih banyaknya pengusaha tekstil yang belum membayar buruh sesuai dengan upah minimum, sangat terkait dengan mekanisme penetapan upah minimum oleh Dewan Pengupahan. Gubernur menetapkan besarnya upah minimum berdasakan rekomendasi Dewan Pengupahan Propinsi dan/ atau Bupati/ Walikota. Dalam prakteknya, Dewan Pengupahan Kabu-paten/ Kota melakukan survei pasar untuk bisa menentukan besarnya KHL karena besarnya upah minimum diarahkan pada pencapaian KHL. Untuk itu Dewan pengupahan melakukan simulasi dengan membeli 60 komponen hidup layak sesuai dengan Peraturan Menteri Tenaga Kerja dan Transmigrasi Nomor 13 tahun 2012. Setelah melakukan survei, anggota dewan pengupahan melakukan rapat untuk menentukan kebutuhan hidup yang layak untuk seorang tenaga kerja dan untuk selanjutnya merekomendasikan besarnya upah minimum kepada Bupati untuk ditetapkan oleh Gubernur.

Mengenai KHL ini, kalangan pengusaha juga mempunyai argumen sendiri. "Layak itu kan relatif, tidak sama untuk semua orang. Dan lagi, KHL tidak membedakan kualitas kerja seorang karyawan sehingga pada saat penentuan upah minimum semua karyawan dianggap sama kualitasnya. Perusahaan harus membayar upah tenaga kerja tanpa membedakan yang skill dan unskill. Dengan alasan ini maka sebagian besar pengusaha tekstil, khususnya di Kabupaten Bandung tidak membayarkan upah sesuai dengan upah minimum, tetapi atas dasar upah borongan. Dengan dasar upah borongan ini maka jumlah upah yang diterima oleh buruh bisa mendekati atau malah melebihi upah minimum.

\section{Dampak Kenaikan Upah Minimum Bagi Perusahaan}

Seperti telah dijelaskan sebelumnya, kenaikan upah minimum yang terjadi setiap tahunnya bukan hanya menjadi beban psikologis bagi pengusaha namun juga secara nyata berdampak pada kemampuan perusahaan untuk berinvestasi pada mesin-mesin produksi yang menggunakan teknologi yang lebih baru. Besarnya tekanan yang dihadapi oleh pengusaha menjelang penentuan upah minimum setiap tahun lebih disebabkan karena ancaman mogok dan aksi yang akan dilakukan buruh jika kenaikan upah tersebut tidak sesuai dengan yang mereka inginkan. Dan ini sudah menjadi pemandangan yang rutin setiap tahunnya terutama pada bulan oktober sampai dengan Nopember dimana pada saat itu dewan pengupahan mulai menjalankan tugasnya.

Hasil penelitian ini menunjukkan bahwa meskipun telah membayar buruh sesuai dengan ketentuan upah minimum, namun tidak berarti kenaikan tersebut tidak memberatkan perusahaan. Sebagai contoh, UMK Sumedang pada tahun 2013 adalah Rp 1.381.700,00. Angka ini mengalami kenaikan yang cukup besar pada tahun 2014 dimana UMK Sumedang ditetapkan Rp. 1.735.473,00. Artinya, ada kenaikan upah sebesar Rp 353.773,00 pada tahun 2014. Dengan jumlah tenaga kerja 35 ribu orang, PT. Kahatex yang berlokasi di Sumedang harus mengeluarkan $\mathrm{Rp} \quad$ 12,38 milyar untuk kenaikan upah tenaga kerja dalam satu bulan. Dengan tambahan biaya tenaga kerja yang demikian besar, perusahaan tidak mendapatkan manfaat apapun dari kenaikan upah ini. Dan yang lebih penting lagi, apakah perusahaan mendapatkan tambahan keuntungan sebesar Rp 12 milyar dalam sebulan untuk menutupi tambahan beban tenaga kerja ini? Jika tidak, maka kenaikan upah ini hanya akan menggerogoti modal kerja perusahaan. Kenaikan upah yang tidak diikuti oleh peningkatan produktifitas ini pada akhirnya akan menyebabkan terjadi decline.

Secara teoritis, kenaikan upah minimum yang diberikan perusahaan seharusnya bisa meningkatkan partisipasi tenaga kerja dan memotivasi mereka untuk berkinerja lebih baik. Setidaknya inilah yang diharapkan oleh pengusaha pada saat mereka memberikan kenaikan upah pada pekerja, yaitu adanya motivasi untuk meningkatkan produktifitas kerja dan komitmet pada perusahaan. Meskipun uang bukanlah segalanya, namun fakta bahwa banyak pekerja pindah ke pabrik yang lebih besar dengan alasan upah yang lebih tinggi tidak bisa menutupi asumsi bahwa pekerja hanya termotivasi oleh uang adalah benar. Dan seharusnya peningkatan produktifitas akan terjadi pada saat pekerja sudah mendapatkan upah sebagaimana yang mereka diinginkan.

Namun hasil dari penelitian ini tidak menunjukkan adanya dampak yang positif dari kenaikan upah terhadap produktifitas pekerja. Hal ini tidak saja terjadi pada perusahaan besar seperti PT Kahatex yang selalu menaikkan upah setiap tahunnnya sesuai dengan standar upah minimum, tetapi juga pada perusahaan kecil dan menengah yang secara komulatif telah membayarkan upah di atas upah minimum. Penelitian yang dilakukan Mulyati terkait dengan tingkat upah dan produktifitas tenaga di sektor industri di Jawa Barat menunjukkan bahwa tingkat upah yang diterima di beberapa daerah berada di atas tingkat produktivitas yang disumbangkan. Dengan kata lain, tingkat produktivitas tenaga kerja sektor industri di beberapa kabupaten/kota di Jawa Barat masih terlihat rendah. Artinya, Tidak adanya dampak postif dari kenaikan upah terhadap produktifitas pekerja bukan hanya menjadi fenomena saat ini tetapi sudah berlangsung lama.

Para pengusaha tekstil mengatakan bahwa "kenaikan upah setiap tahunnya hanya membebani perusahaan, hanya menenggang inflasi dan tidak ada kaitannya dengan peningkatan produktifitas dan keuntungan bagi perusahaan. Upah dinaikkan atas dasar kemanusiaan. Jika apa yang dikatakan oleh kalangan pengusaha ini benar, maka inefisiensi tenaga kerja merupakan salah satu penyebab tingginya biaya produksi dan terjadinya ekonomi biaya tinggi. Artinya, kenaikan upah minimum yang ditetapkan oleh pemerintah justru berdampak buruk terhadap industri tekstil yang notabene merupakan industri pengolahan yang padat karya. Dampak negatif dari kenaikan upah juga dirasakan oleh CV. SML di Majalaya, yang harus kehilangan karyawannya karena pindah ke perusahan besar yang sudah memberikan upah minimum. Mengenai dampak buruk ini, pemiliki PT SSC mengatakan bahwa "hal ini terjadi karena penetapan upah bukan lagi atas dasar kebutuhan riil pekerja tetapi sudah menjadi agenda untuk 
kepentingan politis. Artinya, ada incentive compatible yang diperoleh oleh pihak-pihak tertentu dengan naiknya upah buruh, setidak-tidaknya dalam bentuk pencitraan.

Kenaikan upah minimum bukan hanya tidak berdampak terhadap produktifitas tenaga kerja dan terjadinya mutasi tenaga kerja tetapi juga berdampak negatif terhadap daya saing perusahaan. Pelan namun pasti, kenaikan ini akan menggerogoti modal kerja perusahaan. Hal ini terjadi karena kenaikan upah hanya berpotensi untuk meningkatkan biaya produksi. Tanpa diikuti oleh kenaikan volume penjualan maka dalam beberapa tahun kedepan perusahaan akan mengalami kesulitan karena tingginya komponen biaya produksi dan akhirnya ditutup kerena sudah tidak mampu membayar upah. Karena itu, sangat beralasan jika dikatakan bahwa kita telah gagal dalam mempertahankan daya saing industri tekstil.

Kenaikanupahminimumbukanhanyaterjadidalam 5 tahun terkahir, tetapi sudah ada sejak dikeluarkannya Peraturan Menteri Tenaga Kerja Nomor 01 Tahun 1999 Tentang Upah Minimum. Ini berarti bahwa kenaikan upah minimum sudah terjadi selama 14 tahun, dan dalam kurun waktu tersebut memang ada banyak perusahaan tekstil yang harus ditutup karena sudah tidak mampu bersaing. Menurut Penelitian yang dilakukan oleh Sari, dalam kurun waktu 5 tahun terakhir terdapat 227 pabrik tekstil yang berlokasi di Jawa Barat yang ditutup. Angka ini juga didukung oleh data dari Dinas Perindustrian dan Perdagangan Propinsi Jawa Barat bahwa pada tahun 2005 terdapat 3.025 perusahaan TPT di Jawa Barat dan pada tahun 2010 tersisa 713 perusahaan.

Data tahun 2012 menunjukkan bahwa terdapat 670 perusahaan yang bergerak dibidang tekstil dan produk tekstil di Jawa Barat. Artinya, keberadaan perusahaan tekstil di Jawa Barat menunjukkan adanya penurunan jumlah dari tahun ke tahun. Jumlah ini akan semakin turun jika perusahaan yang ada sekarang tidak segera melakukan perubahan dan beroperasi secara efisien. Salah satu upaya yang dapat dilakukan adalah dengan menurunkan biaya tenaga kerja

Tujuan dari aturan pengupahan adalah untuk melindungi tenaga kerja. Namun aturan juga jangan sampai menghalangi pertumbuhan perusahaan sehingga daya saingnya menjadi rendah dan kemampuan untuk menerima tenaga kerja dan membayar upah juga rendah. Menurut Steiner \& Steiner, aturan ketenagakerjaan harus bisa menyeimbangkan antara perlindungan pekerja dan daya saing Karena itu fleksibelitas tenaga akan lebih menguntungkan baik bagi pekerja maupun bagi perusahaan, meskipun untuk sementara waktu hal ini tidak menyenangkan bagi pekerja. Gambaran tentang trade-off dalam aturan ketenagakerjaan ini digambarkan oleh Steiner \& Steiner pada gambar 1.

Jika mengacu pada ide fleksibelitas yang dikemukakan oleh Steiner \& Steiner di atas maka gambaran yang diperoleh dari hasil penelitian ini adalah bahwa aturan upah minimum yang diterapkan di pada industri tekstil di Jawa Barat secara umum berjalan ke arah inflexible. Hal ini terlihat dari sulitnya perusahaan untuk menanggulangi akibat dari kenaikan upah. Sampai saat ini perusahaan belum mempunyai cara yang tepat untuk menutupi kenaikan upah ini dari kecuali berusaha untuk beralih ke teknologi produksi yang lebih padat modal. Dengan demikian, secara perlahan biaya tenaga kerja akan bisa dikurangi karena mesin produksi yang digunakan tidak membutuhkan banyak tenaga kerja manusia. Untuk saat ini, industri tekstil mengalami dilema antara bertahan dengan padat karya atau beralih ke industri yang lebih padat modal.

Gambar 1. Trade-off in Labour Regulation

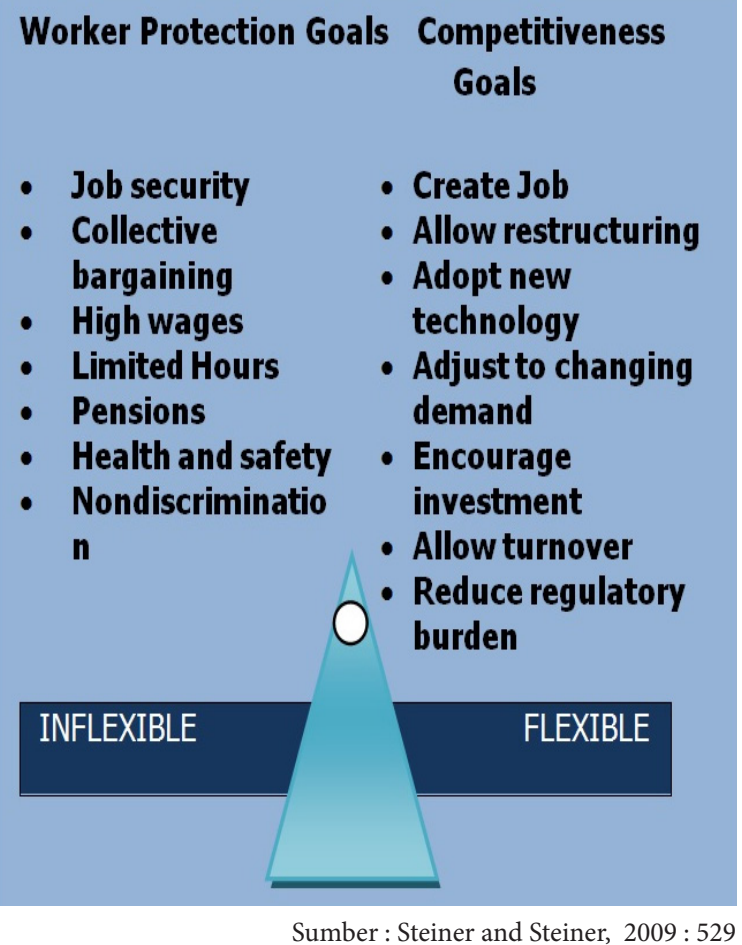

Adanya wacana untuk membawa perusahaan kearah penggunaan mesin produksi yang lebih moderen nampaknya sudah menjadi suatu keharusan untuk mengurangi biaya tenaga kerja dan menjadikan perusahaan lebih efisien. Kenaikan upah yang progresif setiap tahunnya baru akan dirasakan perusahaan dalam 5 tahun ke depan, yaitu semakin berkurangnya kemampuan untuk berinvestasi dan mempertahankan eksistensinya. Saat ini perusahaan harus mempekerjakan karyawan yang tidak terampil yang jumlahnya banyak dan minta upah yang sama dengan pekerja yang terampil. Oleh sebab itu, strategi yang paling tepat adalah dengan mengurangi penggunaan tenaga kerja yang tidak terampil dan menggantikannya dengan mesin-mesin yang dijalankan oleh karyawan yang terampil. Apa yang diungkapkan oleh pengusaha tekstil ini bukanlah reaksi yang berlebihan atas pelaksanaan upah minimum. Datta, $\mathrm{dkk}^{1}$ juga mengatakan bahwa untuk bisa meningkatkan daya saing industri tekstil, maka perusahaan dengan mengurangi intensitas tenaga kerja dan bergerak ke arah intensitas produksi yang lebih padat modal dan teknologi.

\footnotetext{
Datta Anusua, Susan Christoffersen, D.K. Malhotra, Philip Russel \& Helmut Hergeth. 2004. Strategies for Increasing Competitiveness of the Domestic Textile Industry. National Textile Center Research Briefs Management Systems Competency: June 2004. Page $1-10$ http://papers.ssrn.com/sol3/papers.cfm diakses 23 Maret 2012)
} 


\section{Peran Pemerintah Dalam Pelaksanaan Aturan Upah Minimum}

Dalam rangka pelaksanaan aturan ketenagakerjaan khususnya aturan pengupahan, pemerintah mem-punyai kewajiban untuk melakukan pembinaan dan pengawasan. Sesuai dengan pasal 173 UU Nomor 13 Tahun 2003, pemerintah melakukan pembinaan terhadap unsur-unsur dan kegiatan yang berhubungan dengan ketenagakerjaan. Pembinaan dan pengawasan yang dilakukan oleh pegawai pengawas dilakukan dengan melakukan kunjungan ke perusahaan untuk melihat pelaksanaan aturan upah minimum.

Dalam prakteknya, tidak semua perusahaan tekstil yang dikunjungi petugas meskipun perusahaan itu yang secara formal memiliki izin. Temuan di lapangan menunjukkan bahwa baik di Kabupaten Bandung maupun Sumedang, perusahaan tekstil yang dikunjungi adalah perusahaan yang termasuk skala menengah dan besar serta memiliki jumlah tenaga kerja yang banyak. Sedangkan perusahaan yang memiliki tenaga kerja di bawah 50 orang jarang sekali dikunjungi untuk pemeriksaan, apalagi untuk dibina. Adanya perbedaan perlakuan ini disebabkan karena secara kuantitas jumlah pegawai pengawas yang ada tidak sebanding dengan jumlah perusahaan yang harus diawasi. Untuk Kabupaten Sumedang misalnya, hanya ada 5 orang pegawai pengawas untuk mengawasi sekitar 845 perusahaan. Namun meskipun dengan jumlah pengawas yang terbatas, ternyata pegawai pengawas masih bisa mendatangi PT. Kahatex sebulan sekali dengan obyek pemeriksaan yang berbeda-beda. Ini menunjukkan bahwa petugas melakukan "tebang pilih" terhadap perusahaan yang akan dikunjungi. Ada kecenderungan bahwa perusahaan yang dikunjungi hanyalah perusahaan yang memiliki tenaga kerja yang banyak, dan sangat berpotensi untuk melakukan pelanggaran. Tetapi apakah hanya itu alasannya? Ternyata tidak. Ada hal lain yang diperoleh pengawas dengan mengunjungi perusahaan besar, dan ini tidak akan didapatkan jika mereka mengunjungi perusahaan kecil dan menengah, yaitu adanya "sekedar jamuan makan dan minum". Hal ini tidak berbeda dengan yang terjadi di Kabupaten Bandung yang hanya memiliki 5 orang pegawai pengawas. Dengan jumlah perusahaan yang begitu banyak, setiap pegawai pengawas mempunyai program kerja untuk mengunjungi maksimal 5 perusahaan setiap bulannya. Artinya, dalam sebulan hanya 25 perusahaan yang akan dikunjungi.

Menurut pengakuan pengusaha, dalam melakukan pemeriksaan, pegawai pengawas menanyakan beberapa hal yang terkait dengan pelaksanaan upah minimum di perusahaan. Mereka juga memeriksa dan melakukan pemeriksaan silang kepada buruh. Selain itu mereka juga berhak untuk melihat buku upah. Dan dalam kesempatan ini, selalu saja ada oknum pengawas yang nakal, mencaricari kesalahan perusahaan sehingga mereka memiliki sesuatu yang bisa ditawarkan ke perusahaan. Perilaku aparat yang seperti ini akhirnya menciptakan aturan informal, yaitu konvensi untuk memberikan jamuan makan siang, uang transport, dan bahkan uang saku kepada pengawas disamping uang suap yang harus disiapkan jika perusahaan melakukan pelanggaran. Praktek pengawasan dan pembinaan yang seperti ini jelas menjadi cost bagi perusahaan. Setiap pelanggaran yang dilakukan bisa ditransaksikan dengan sejumlah uang oleh oknum petugas. Hal inilah yang dikuatirkan oleh Williamson' 1981 bahwa setidaknya ada sebagian agent yang berperilaku oportunis sehingga praktek kelembagaan tidak bisa efisien. Artinya, tugas pembinaan yang dilakukan oleh pemerintah telah dimanfaatkan oleh oknum pengawas untuk mencari keuntungan pribadi. Hal ini diperparah oleh budaya masyarakat yang sangat permisif dan menjadikan suap/gratifikasi sebagai hal yang biasa (Irawati, 2013). Baik oknum aparat maupun pengusaha menerima insentif dari transaksi ini. Dengan demikian, meskipun ada nota pemeriksaan, surat teguran, pemanggilan secara patut, ataupun law enforcement namun selama ini belum ada yang sampai ke tahap penegakan hukum.

Kondisi seperti dijelaskan di atas, menunjukkan bahwa ada dua aspek yang perlu mendapat perhatian dalam tata kelola kelembagaan pengupahan pada industri tekstil di Jawa Barat, yaitu pertama, aspek mekanisme penetapan upah minimum yang cenderung kurang merperhatikan kondisi riil perusahaan. Dan kedua, aspek penegakan aturan pengupahan yang masih lemah dan membuka peluang bagi munculnya perilaku oportunis dikalangan oknum pegawai pengawas maupun kalangan pengusaha.

\section{SIMPULAN}

Dari uraian di atas dapat disimpulkan bahwa kelembagaan pengupahan pada industri tekstil di Jawa Barat tidak terlepas Undang-Undang Nomor 13 Tahun 2003 tentang Ketenagakerjaan dan Peraturan Menteri Tenaga Kerja dan Transmigrasi Nomor 7 Tahun 2013 sebagai landasan formal. Kelembagaan pengupahan ditandai oleh masih banyak perusahaan tekstil yang melanggar aturan pengupahan dengan membayar buruh di bawah ketentuan upah minimum. Hambatan dalam kelembagaan pengupahan ini adalah karena mekanisme penetapan upah minimum yang kurang memperhatikan kondisi riil perusahaan tekstil. Disamping itu ada keengganan pengusaha untuk melaksanakan aturan pengupahan karena masih lemahnya upaya penegakan aturan formal. Akibatnya, muncul aturan informal berupa konvensi untuk memberikan uang suap kepada oknum pengawas sebagai insentif atas kunjungan yang mereka lakukan ke perusahaan.

\section{DAFTAR PUSTAKA}

Asosiasi Pertekstilan Indonesia (API). 2012. Indonesian Textile \& Garment: Guiding Book 2012 - 2014. Sixth Edition.

Datta, A., Christoffersen, S., Malhotra, D.K., Russel, P. \& Hergeth, H. 2004. Strategies for Increasing Competitiveness of the Domestic Textile Industry. National Textile Center Research Briefs 
Management Systems Competency: June 2004. Page 1 - 10 (http://papers.ssrn.com/sol3/papers. cfm diakses 23 Maret 2012)

De Cenzo, David, A and Robbins, S.P. 1999. Human Resource Management. Sixth Edition. John Wiley \& Sons. New York.

Eriksson, S, Gun. 2005. Supporting the Development of Institutions-Formal and Informal Rules: An Evaluation Theme Basic Concepts. UTV Working Paper 2005:3 Department for Evaluation and Internal Audit SWEDISH INTERNATIONAL DEVELOPMENT COOPERATION AGENCY. page $1-37$.

Irawati. 2013. Kearifan Lokal dan Pemberantasan Korupsi Dalam Birokrasi. Mimbar Vol. 29, No. 1 (Juni 2013). Bandung : Unisba

Klijn, E.H \& Joop, F.M. Koppenjan. 2006. Institutional Design: Changing institutional features of networks. Public Management Review. Vol. 8 Issue 12006 141-160 ISSN 1471-9037 print/ISSN 1471-9045 online-2006 Taylor \& Francis http://www.tandf.co.uk/journals

Mulyati, D. S., Bachtiar, I. dan Rezeki, Y.S. 2006. Pengukuran Produktivitas.

North, D.C. 1990. Institutions, Institutional Change and Economic Performance. Cambridge: Cambridge University Press
North, D.C. 1991. Institutions. The Journal of Economic Perspectives,

Peraturan Menteri Tenaga Kerja dan Transmigrasi Nomor 13 tahun 2012 Tentang Komponen dan Pelaksanaan Tahapan Pencapaian Kebutuhan Hidup Layak

Peraturan Menteri Tenaga Kerja dan Transmigrasi Nomor 7 Tahun 2013 Tentang Upah Minimum Relatif dan Analisis Tingkat Upah Terhadap Produktivitas Tenaga Kerja Sektor Industri di Jawa Barat. Mimbar Volume 22, No. 2 Tahun 2006. hal 185 - 205. Bandung: Unisba

Sari, Y. 2007. Saatnya Pemerintah Buat Kebijakan Melindungi Industri TPT. Artikel. Bandung: Yayasan Akatiga.

Steiner, J.F and Steiner, GA. 2009. Business, Government, And Society: A Managerial Perspective, Text And Cases. Twelfth Edition. New York : McGraw-Hill

Undang-Undang Republik Indonesia No 13 Tahun 2003 Tentang Ketenagakerjaan

Williamson, O.E. 1981. The Economics of Organization: The Transaction Cost Approach. American Journal of Sociology. Volume 87. Issue 3 November 1981 p 548 - 577 
Kelembagaan Pengupahan pada Industri Tekstil di Jawa Barat

(Erna Maulina dan Nur Efendi) 